\title{
Rancang Bangun Sistem Informasi Monitoring Limbah B3 (Studi Kasus: PT. PJB UP Gresik)
}

\author{
Imroatul Fadlilah ${ }^{1}$, Deny Andesta ${ }^{2}$, Said Salim Dahda ${ }^{3}$ \\ Program Studi Teknik Industri, Fakultas Teknik, Universitas Muhammadiyah Gresik, Sumatera 101 \\ GKB, Gresik 61121 \\ Email:iim.fadlilah@gmail.com
}

\begin{abstract}
Abstrak : Sejak tahun 2011, industri di dunia sedang memasuki era Industri 4.0, dimana semua kegiatannya memanfaatkan perkembangan teknologi digital yang semakin pesat. Sejalan dengan hal tersebut, PT PJB UP Gresik memiliki rencana jangka panjang perusahaan yang mendukung pada peningkatan digitalisasi perusahaan, demi tercapainya kinerja yang cepat, akurat dan efisien. Disisi lain, untuk pencatatan kegiatan pengelolaan limbah B3 masih dilakukan secara manual diatas kertas sebanyak 480 menit atau 37,2\% dari total alokasi waktu. Pencatatan manual menyebabkan terupdatenya data yang disimpan menjadi lebih lama. Selain itu, metode pencatatan tersebut tidak sesuai dengan era sekarang, sehingga perlu dibuat manajemen data dengan sistem informasi berbasis Website. Pembuatan sistem informasi ini dapat meningkatkan fleksibilitas perusahaan untuk menyimpan dan memperoleh data tentang limbah B3 yang masuk maupun keluar dari gudang limbah B3, serta dapat memberikan penghematan waktu pekerjaan pengelolaan limbah B3 sebanyak 1035 menit dalam setahun.
\end{abstract}

Kata Kunci : Pengelolaan limbah B3, Penghematan waktu, Teknologi digital, dan Website

\section{Pendahuluan}

Sejak tahun 2011, industri di dunia sedang memasuki era Industri 4.0, dimana semua kegiatannya memanfaatkan perkembangan teknologi digital yang semakin pesat (Hoedi \& Prasetyo, 2017). Internet of things sangat erat hubungannya dengan Revolusi Industri 4.0 karena IoT adalah unsur utama dalam revolusi industri 4.0. IoT berpengaruh dalam berbagai macam industri seperti manufaktur, logistik, kesehatan, tata kota, rumah, pertanian, bahkan industri otomotif. Fungsi utama IoT pada dasarnya sebagai data miner. IoT bekerja mencari dan mengumpulkan berbagai data dari lapangan yang nantinya akan diolah menjadi data yang lebih bermanfaat. (Rauf, 2018).

PT PJB UP Gresik merupakan industri pembangkitan listrik yang memiliki visi menjadi perusahaan terpercaya dalam bisnis pembangkitan terintegrasi dengan standar kelas dunia. Perusahaan ini memiliki Rencana Jangka Panjang (RJPU) 2018 - 2022 yang salah satunya mendukung perkembangan teknologi informasi. Strategi tersebut adalah Enhance IT Process and Capabilities, yaitu meningkatkan kapabilitas dan proses IT terintegrasi yang baik sebagai enabler dalam menghantarkan informasi yang diperlukan secara cepat, akurat, dan efisien untuk membantu dalam pengambilan keputusan, dengan Key
Performance Indicator (KPI) nya adalah \% ketersediaan layanan teknologi informasi (Tim RJPU, 2018).

PT PJB UP Gresik menghasilkan Limbah B3 dari proses produksi maupun proses penunjangnya (Tim PROPER, 2018). Limbah tersebut telah dikelola sesuai dengan peraturan perundangan yang berlaku. Pengelolaan Limbah B3 yang dilakukan adalah dengan penyimpanan pada gudang/ TPS (Tempat Penyimpanan Sementara) Limbah B3 dengan ijin penyimpanan berdasarkan Keputusan Kepala Dinas Penanaman Modal dan PTSP Kabupaten Gresik Nomor : 503.6.2/03/437.74/2017 dengan masa berlaku selama 5 tahun (Laporan PLB3, 2018).

$$
\text { Berdasarkan dokumen Sistem }
$$

Manajemen Lingkungan (ISO14001:2015) Proses pengelolaan Limbah B3 di PT PJB UP Gresik diatur oleh Instruksi Kerja Nomor : IKG08.2.2.49 tentang Pemantauan dan Pelaporan Pengelolaan Limbah B3. Secara garis besar dapat disampaikan dalam bagan dibawah ini : 


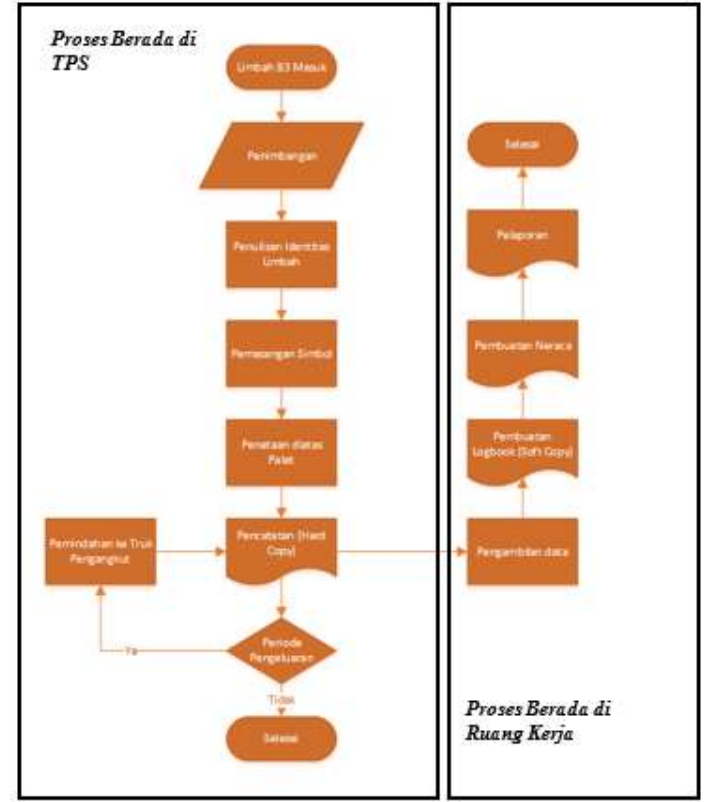

Gambar 1. Proses Pengelolaan Limbah B3 PT PJB UP Gresik

Berdasarkan gambar diatas, penghasil (bidang lain yang menghasilkan limbah B3) menyerahkan limbah B3 kepada bidang lingkungan. Kemudian oleh bidang lingkungan limbah tersebut disimpan didalam TPS/ gudang selama maksimal 90 hari. Didalam gudang, limbah B3 sebelum diletakkan diatas palet terlebih dahulu ditimbang dan diberikan label identitas limbah dan simbol bahaya disetiap kemasannya. Selanjutnya bidang lingkungan, mencatat identitas limbah yang masuk di kertas logbook dan papan informasi yang ada digudang.

Setiap 3 bulan, staff lingkungan melakukan rekapitulasi jumlah limbah B3 yang ada di gudang. Proses rekapitulasi tersebut dilakukan dengan mengambil kertas logbook terlebih dahulu di TPS. Jarak antara ruangan staff dengan TPS $\pm 1 \mathrm{~km}$, dan hanya dapat ditempuh dengan berjalan kaki \pm 20 menit. Kemudian kertas logbook dibawa ke ruang staff, untuk di rekapitulasi dengan Microsoft excel. Data tersebut dibutuhkan untuk menentukan jumlah armada yang akan digunakan pihak ketiga untuk mengangkut limbah yang ada.
Pada saat proses pengangkutan limbah dengan pihak ketiga, staff lingkungan membawa kertas logbook kembali ke gudang, untuk mencatat identitas limbah yang keluar. Setelah proses pengangkutan selesai, kertas logbook dibawa kembali ke ruangan staff untuk direkap kembali kegiatan pengangkutan tersebut di Microsoft Excel. Output dari kegiatan rekapitulasi tersebut adalah logbook dan neraca limbah yang akan dilaporkan ke dinas lingkungan terkait.

Dari pengamatan dilapangan, dapat dihitung alokasi waktu untuk tahapan proses diatas dengan stopwatch. Dimana, alokasi waktu pada kegiatan penerimaan dan pengeluaran limbah B3 pada tabel dibawah ini berlaku untuk penanganan 1 kemasan limbah. Sedangkan untuk alokasi waktu dalam setahun diasumsikan bahwa setiap 3 bulan dalam 1 tahun jumlah limbah yang masuk sama sebanyak 22 kemasan (Asumsi berdasarkan Berita Acara pengeluaran limbah triwulan 1 tahun 2018). Kemudian, untuk alokasi waktu kegiatan pelaporan rutin berlaku setiap triwulan (3 bulan sekali). Dari tabel tersebut, dapat diketahui bahwa masih terdapat proses pencatatan yang masih secara manual diatas kertas sebanyak 480 menit atau 37,2\% dari total alokasi waktu. Hal ini tidak sejalan dengan rencana jangka panjang perusahaan yang mendukung pada peningkatan digitalisasi perusahaan, demi tercapainya kinerja yang cepat, akurat dan efisien.

Tabel 1. Alokasi Waktu Pengelolaan Limbah B3 selama 1 tahun

\begin{tabular}{|c|c|c|c|}
\hline No. & Pekerjaan & $\begin{array}{c}\text { Alokasi } \\
\text { Waktu } \\
\text { (Menit) }\end{array}$ & $\begin{array}{c}\text { Alokasi Waktu } \\
\text { dalam setahun } \\
\text { (Menit) }\end{array}$ \\
\hline \multicolumn{4}{|c|}{ Penerimaan Limbah B3 } \\
\hline 1 & Penimbangan limbah B3 yang masuk & 10 & 880 \\
\hline 2 & $\begin{array}{l}\text { Penulisan identitas limbah di stiker dan } \\
\text { penempelan }\end{array}$ & 5 & 440 \\
\hline 3 & Penempelan simbol limbah B3 & 2 & 176 \\
\hline 4 & Penataan limbah di atas palet & 10 & 880 \\
\hline 5 & $\begin{array}{l}\text { Pencatatan limbah masuk di papan } \\
\text { informasi }\end{array}$ & 10 & 880 \\
\hline 6 & $\begin{array}{l}\text { Pencatatan limbah masuk di formulir } \\
\text { logbook di TPS }\end{array}$ & 10 & 880 \\
\hline \multicolumn{4}{|c|}{ Pengeluaran Limbah B3 } \\
\hline 7 & $\begin{array}{l}\text { Pemindahan limbah dari TPS ke Truk } \\
\text { pengangkut }\end{array}$ & 15 & 1320 \\
\hline 8 & Pencatatan limbah keluar di papan informasi & 5 & 440 \\
\hline 9 & Pencatatan limbah keluar di logbook & 5 & 440 \\
\hline \multicolumn{4}{|c|}{ Pelaporan Rutin } \\
\hline 10 & $\begin{array}{l}\text { Pengambilan data logbook limbah B3 di } \\
\text { TPS }\end{array}$ & 50 & 200 \\
\hline 11 & $\begin{array}{l}\text { Pembuatan data logbook ke dalam bentuk } \\
\text { excel }\end{array}$ & 120 & 480 \\
\hline 12 & Pembuatan Neraca Limbah B3 & 60 & 240 \\
\hline 13 & Pembuatan laporan PLB3 & 480 & 1920 \\
\hline Total & & 782 & 9176 \\
\hline
\end{tabular}


Berdasarkan permasalahan diatas, dengan pencatatan manual menyebabkan terupdatenya data yang disimpan menjadi lebih lama. Selain itu, metode pencatatan tersebut tidak sesuai dengan era sekarang, sehingga perlu dibuat manajemen data dengan sistem informasi berbasis Website. Pembuatan sistem informasi ini dapat meningkatkan fleksibilitas perusahaan untuk menyimpan dan memperoleh data. Website tersebut akan digunakan untuk menyimpan semua data limbah yang masuk maupun keluar dari gudang limbah B3. Dimana, data limbah B3 disimpan kedalam bentuk $Q R$ Code yang ditempel di kemasan limbah. Saat proses pengeluaran limbah hanya perlu melakukan scanning pada $Q R$ Code yang ada. Sehingga histori data limbah yang masuk dan keluar dapat disimpan langsung pada sistem. sistem informasi berbasis internet ini dapat memberikan beberapa keuntungan, diantaranya pertama, lebih mudah dan cepat untuk memonitor data limbah B3 aktual tanpa perlu melihat data di gudang. Kedua, fungsi papan informasi dapat digantikan dengan layar LCD yang diletakkan digudang, untuk menampilkan data limbah aktual yang disimpan di TPS. Ketiga, mengurangi limbah kertas yang digunakan untuk logbook manual. Keempat, data logbook dapat langsung ditarik dari database, sehingga data dapat langsung digunakan untuk pelaporan rutin.

Penelitian ini akan membahas tentang perancangan sistem informasi pengelolaan limbah B3 di PT PJB UP Gresik. Dimana dalam penelitian ini akan dilakukan pemodelan sistem informasi yang akan dibuat. Diharapkan dengan adanya penelitian ini, akan membantu perusahaan untuk membuat sitem informasi yag memudahkan dan mempercepat pekerjaan.

\section{Metode Penelitian}

Dalam mencari solusi dari sebuah penelitian yang diamati tentang rancang bangun sistem informasi monitoring limbah B3, dibutuhkan langkah - langkah untuk menguraikan pendekatan dan model dari masalah tersebut, yaitu :

1. Identifikasi Masalah

Identifikasi masalah adalah langkah pertama dalam melakukan penelitian ini. Pada tahap ini dilakukan identifikasi terhadap beberapa permasalahan pada proses pengelolaan limbah B3 terutama pada sistem administrasi.

2. Studi Lapangan
Studi lapangan bertujuan untuk melakukan observasi lapangan secara langsung pada proses pengelolaan limbah B3, membaca laporan pengelolaan limbah B3, membaca logbook yang ada di Tempat Penyimpanan Sementara (TPS), dan wawancara pada karyawan.

3. Studi Literatur

Pada tahap ini dilakukan pembelajaran terhadap pembuatan IDEF0 untuk memodelkan sistem pengelolaan limbah B3, pembuatan ERD (Entity Relationship Diagram) untuk menyusun relasi antar sistem, serta literature tentang sistem informasi berbasis komputer. Studi literatur diperoleh dari berbagai sumber, baik dari buku maupun dari tugas akhir yang dijadikan referensi untuk memperoleh data dan teori-teori yang dibutuhkan untuk mendukung dalam melakukan penelitian.

4. Pengumpulan Data

Pada tahap ini akan melakukan pengumpulan data yang dibutuhkan dalam penelitian, yaitu data primer dan data sekunder. Data primer adalah data yang didapat dari penelitian secara langsung dengan cara menanyakan ke sumber yang memberikan informasi.

Pengumpulan data primer dapat dilakukan dengan beberapa macam cara antara lain :

a. Teknik Wawancara / interview

Yaitu suatu teknik pengumpulan data dengan cara mengadakan wawancara secara langsung dengan supervisor dan staff bidang lingkungan untuk menggali informasi terkait dengan sistem administrasi pengelolaan limbah B3 di gudang/ TPS Limbah B3 yang ada saat ini, diantaranya :

- Identifikasi kebutuhan fungsional sistem informasi, dengan melakukan wawancara pada karyawan bidang lingkungan PT PJB UP Gresik. Kebutuhan fungsional adalah kebutuhan apa saja yang diinginkan oleh perusahaan terhadap sistem informasi yang akan dibuat, seperti informasi terkait jumlah limbah B3 yang masuk, atau nama pihak ketiga yang mengolah limbah B3 yang dihasilkan oleh perusahaan.

- Identifikasi kebutuhan non fungsional, dengan melakukan wawancara pada karyawan bidang teknologi informasi PT PJB UP 
Gresik. Kebutuhan non fungsional adalah kebutuhan apa saja yang digunakan untuk membuat sistem informasi yang diinginkan, baik itu hardware, seperti printer stiker atau

b. Observasi software, seperti My SQL.

Yaitu teknik pengumpulan data pada waktu penelitian dengan melakukan pengamatan langsung pada perusahaan untuk mendapatkan gambaran dan keadaan umum yang aktual terkait dengan pola permintaan.

Data yang dibutuhkan dalam penelitian ini meliputi :

- Data pengukuran waktu kegiatan administrasi (IKG-08.2.2.49) yang berhubungan dengan kegiatan pengelolaan limbah B3, dengan melakukan pengukuran langsung menggunakan stopwatch.

- Data pengeluaran limbah B3, dengan membaca laporan pengelolaan limbah B3 dari bidang lingkungan PT. PJB UP Gresik. Data tersebut diantaranya :

- Jumlah limbah B3 yang telah dikelola pada triwulan I tahun 2018

- Daftar limbah B3 yang boleh disimpan di gudang/ TPS

- Daftar nama perusahaan pemanfaat yang bekerjasama dengan PT PJB UP Gresik

- Daftar nama perusahaan pengangkut yang bekerjasama dengan PT PJB UP Gresik

5. Pengolahan Data

Dari data - data yang diperoleh, kemudian dilakukan pengolahan data sebagai berikut :

a. Pemodelan sistem pengelolaan limbah B3 dengan membuat Flowchart Diagram. Diagram yang dibuat menggambarkan sistem administrasi pengelolaan limbah B3 dari awal hingga akhir.

b. Pembuatan ERD (Entity Relationship Diagram), yang menggambarkan hubungan antar sistem yang telah dibuat, sehingga memudahkan dalam pembuatan database. Diagram yang akan dibuat akan menggambarkan hubungan tabel (Entity) sebagai berikut :
- Tabel database limbah B3 yang boleh disimpan

- Tabel database perusahaan pemanfaat limbah B3

- Tabel database perusahaan pengangkut limbah B3

- Tabel data limbah B3 yang masuk ke gudang

- Tabel data limbah B3 yang keluar dari gudang

c. Rancang bangun sistem informasi dari ERD yang telah dibuat. Pembuatan sistem informasi dilakukan oleh staf bidang teknologi informasi PT PJB UP Gresik.

d. Normalisasi database digunakan untuk menghasilkan struktur tabel yang normal atau baik dari sistem informasi yang telah dibuat. Tabel output dari sistem informasi yang dibuat dinormalisasi kedalam bentuk sejumlah tabel dengan bentuk normal. Normalisasi dimulai dari tahap tidak normal, bentuk normal pertama (1NF), bentuk normal kedua (2NF) dan seterusnya sampai didapatkan struktur tabel yang normal.

e. Verifikasi dan Validasi dilakukan pada sistem informasi yang telah dibuat. Proses tersebut dilakukan dengan memeriksa apakah kebutuhan yang disampaikan oleh user saat perancangan sistem dapat terpenuhi.

6. Analisa dan Intepretasi

Setelah sistem informasi dibuat, kemudian dilakukan analisa dan intepretasi dari sistem informasi yang dibuat. Analisa dilakukan dengan membandingkan sistem yang terjadi saat ini, dengan sistem usulan yang telah dibuat.

7. Kesimpulan dan Saran

Dari penelitian yang telah dilakukan didapat beberapa kesimpulan dari rancang bangun sistem informasi monitoring limbah B3 dan diberikan beberapa saran untuk melakukan pengembangan selanjutnya. 


\section{Hasil dan Pembahasan}

Alur sistem pencatatan dengan menggunakan sistem informasi yang telah dibuat adalah sebagai berikut:

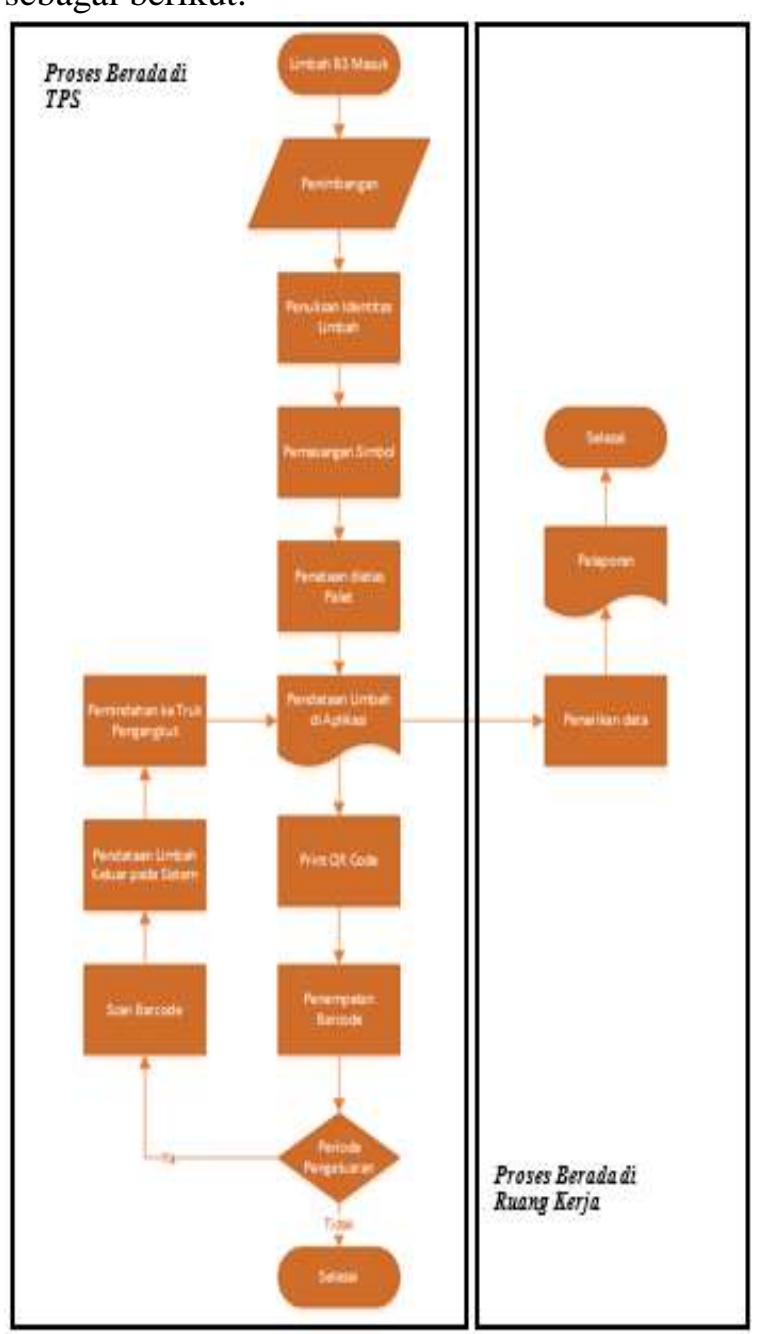

Gambar 2. Alur Sistem Pencatatan dengan Sistem Informasi berbasis Web

Setelah sistem informasi dibuat, sesuai dengan pemodelan yang telah dirancang, dilakukan pengujian lapangan. Pada uji coba lapangan, dilakukan dengan mencoba menggunakan sistem informasi yang telah dibuat, kemudian dilakukan pengukuran waktu yang dibutuhkan ketika menggunakan sistem informasi tersebut. Berikut adalah hasil pengukuran waktu penggunaan sistem informasi :
Tabel 2

Hasil Pengukuran Waktu pencatatan dengan Sistem yang Baru

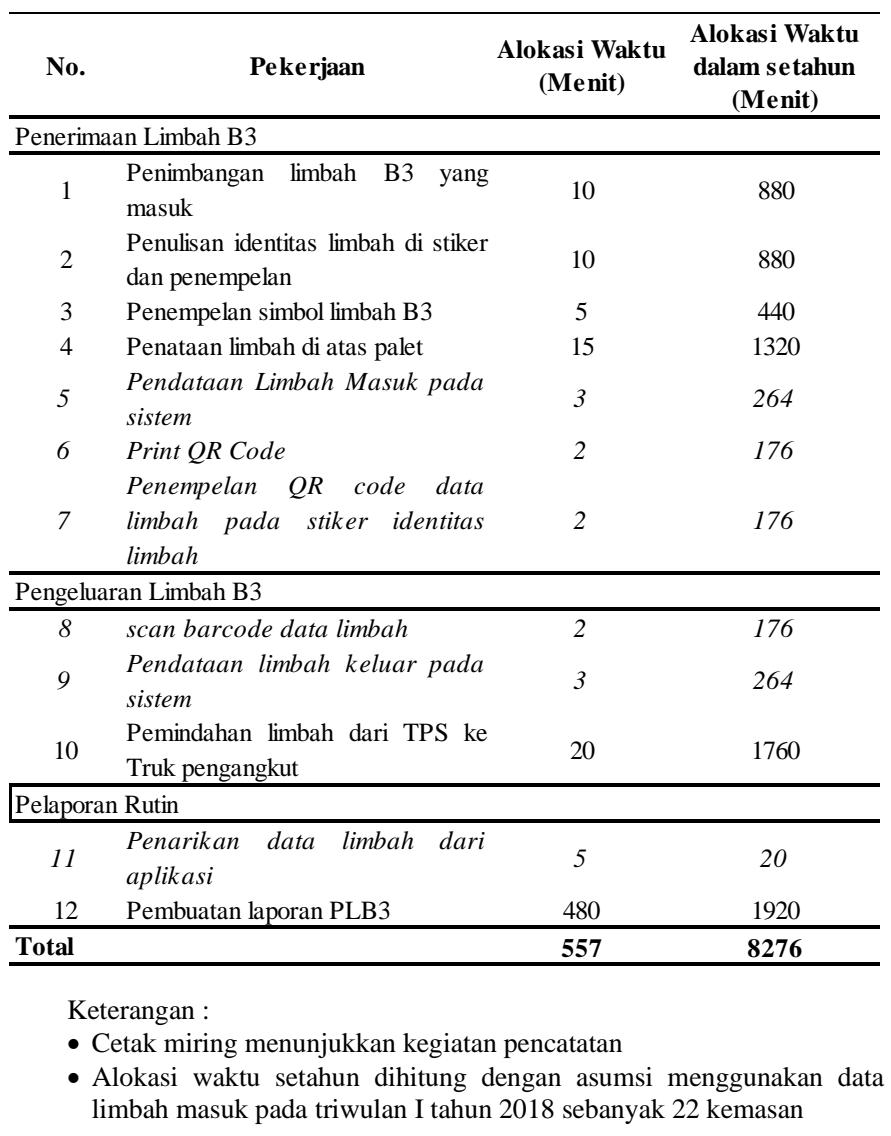

Dari hasil uji lapangan diatas, dilakukan perhitungan \% allowance dan waktu baku, sebagai berikut :

- Perhitungan \%Allowance (Menggunakan metode ILO)

Kelonggaran Pribadi : $2 \%$

Kelonggaran keletihan dasar $: 2 \%$

Tingkat perhatian sangat teliti : $5 \%$

Ketegangan Mental Proses Rumit : $4 \%$

Kebosanan $: 2 \%$

Total Allowance $\quad: 15 \%$

- Perhitungan Waktu Baku :

Waktu Siklus = 8276 Menit

Waktu Normal $=$ Waktu Siklus $\mathrm{x}$

Penyesuaian

Waktu Normal $=8276 \times 100 \%$ 


$$
=8276 \text { Menit }
$$

Waktu Baku = Waktu

Normal + ( Waktu Normal x \% Allowance )

$$
\begin{aligned}
& =8276+(8276 \times 15 \%) \\
& =9517,4 \text { Menit }
\end{aligned}
$$

Berdasarkan perbandingan alokasi waktu pencatatan antara sistem manual dengan sistem informasi berbasis web, dapat dihitung penghematan waktu dengan penerapan sistem pencatatan usulan. Sistem informasi berbasis web dapat memberikan penghematan waktu sebanyak 1035 menit dalam setahun.

\section{Kesimpulan}

Dari pembahasan diatas yang disertai dengan beberapa interpretasi hasil, adapun halhal yang menjadi poin penting dan dapat ditarik suatu kesimpulan ialah sebagai berikut :

- Sistem informasi pengelolaan limbah B3 dimodelkan dengan menggunakan flowchart sederhana. Flowchart tersebut menggambarkan sistem administrasi pengelolaan limbah B3 dari awal hingga akhir. Sistem yang dimaksud diantaranya, pembuatan database nama limbah, nama pemanfaat, nama pengangkut dan riwayat transaksi limbah masuk serta limbah keluar.

- Sistem informasi dibuat menggunakan perangkat lunak bebas XAMPP untuk windows. Setelah pembuatan sistem informasi selesai dibuat, server dipindahkan ke milik perusahaan, sehingga mudah untuk diakses menggunakan internet. Pembuatan sistem informasi ini dapat meningkatkan fleksibilitas perusahaan untuk menyimpan dan memperoleh data tentang limbah B3 yang masuk maupun keluar dari gudang limbah B3, serta dapat memberikan penghematan waktu pekerjaan pengelolaan limbah B3 sebanyak 1035 menit dalam setahun.

\section{Saran}

Dari kesimpulan diatas dapat diberikan saran sebagai berikut :

- Bagi Perusahaan sebagai tempat/obyek penelitian diharapkan agar dapat mengimplementasikan sistem informasi berbasis web yang diusulkan, agar lebih fleksibel dalam menyimpan dan mencari data tentang pengelolaan limbah B3.

- Pada penelitian ini, output sistem informasi yang dibuat hanya berupa logbook limbah B3. Sedangkan dalam pelaporan limbah B3 terdapat 2 jenis catatan yang harus dilaporkan, yaitu logbook dan neraca. Diharapkan untuk peneliti selanjutnya dapat membuat sistem informasi dengan ditambahkan output berupa neraca limbah B3.

- Menu data limbah masuk pada sistem ini terdapat atribut maksimal waktu penyimpanan yaitu maksimal 90 hari, namun hanya dapat diketahui saat membuka sistem informasi ini. Diharapkan untuk peneliti selanjutnya dapat menambahkan fitur pengingat, yaitu pemberitahuan lewat email untuk memberitahukan bahwa limbah B3 yang disimpan sudah mendekati batas waktu penyimpanan. Hal ini agar dapat meningkatkan awareness user terkait untuk segera melaksanakan pengelolaan terhadap limbah B3 yang disimpan.

\section{Daftar Pustaka}

PT PJB UP Gresik. (2017). Laporan Triwulanan Pengelolaan Limbah B3 PT PJB UP Gresik. Gresik.

PT PJB UP Gresik. (2018). Dokumen Ringkasan Kinerja Pengelolaan Lingkungan PT PJB UP Gresik 2017 2018. Gresik.

Prasetyo, H \& Sutopo, W. (2018). Industri 4.0 : Telaah Klasifikasi Aspek dan Arah Perkembangan Riset. Surakarta.

Donnal Putera, Andri. (2018). 5 Industri Utama Disiapkan untuk Revolusi Industri 4.0. Diakses pada 07 Desember 2018 dari https://ekonomi.kompas.com/read/2018/ 04/04/134003826/5-industri-utamadisiapkan-untuk-revolusi-industri-40.

Kementerian Perindustrian RI. (2018). Making Indonesia 4.0. Jakarta

MS, Kusnendi. (2011). Konsep Dasar Sistem Informasi. Bandung.

Tata Sutabri. (2012). Analisis Sistem Informasi. Yogyakarta

Tata Sutabri. (2012). Konsep Sistem Informasi. Yogyakarta

Jogiyanto Hartono MBA. Ph. D. (2004). Pengenalan Komputer. Yogyakarta

Rumapea, S. A. (2010). Analisis Proses Bisnis Pada Distributor XYZ Menggunakan Tools Pemodelan IDEF0, Seminar Nasional Aplikasi Teknologi Informasi. Diakses September 13, 2011 dari http://journal.uii.ac.id/index.php/Snati/ar ticle/view/1886/0 
Bagir, M. Haidar \& Eko Putro, Bramantiyo. (2018). Analisis Perancangan Sistem Informasi Pergudangan di CV. Karya Nugraha. Universitas Suryakencana Cianjur.

Setiawan, Dika Agus. (2017). Perancangan Sistem Inofrmasi Ruang Baca Jurusan Teknik Industri Universitas Muhammadiyah Surakarta Berbasis Website. Universitas Muhammadiyah Surakarta.

Saputra, Sandra, dkk. (2014). Perancangan Sistem Informasi Tugas Akhir II Program Studi Teknik Industri UPN Veteran Yogyakarta Berbasis Website. Universitas Pembangunan Nasional Veteran Yogyakarta.

Dafinci, Febriansyah. (2010). Aplikasi Database Karyawan Outsource pada PT. Limapilar Teknologi. Universitas Islam Negeri Syarif Hidayatullah Jakarta. 